\title{
MENGATASI PERMASALAHAN DAN PENINGKATAN PRESTASI BELAJAR IPA MELALUI KONSELING EKLEKTIF DENGAN PERILAKU ATTENDING PADA SISWA VIII B2 SEMESTER GANJIL TAHUN PELAJARAN 2018/2019 SMP NEGERI 6 SINGARAJA
}

\author{
Oleh \\ Made Sukri, S.Pd \\ Guru Bimbingan Konseling SMP Negeri 6 Singaraja \\ Email:madesukri16@gmail.com
}

\begin{abstract}
ABSTRAK
Tujuan penelitian tindakan bimbingan konseling ini adalah (1) untuk mendiskripsikan peranan konseling dengan teknik Konseling Eklektif dengan Perilaku Attending dapat mengatasi permasalahan belajar siswa dalam mata pelajaran IPA, dan (2) untuk mendiskripsikanperanan konseling dengan teknik Konseling Eklektif dengan Perilaku Attending dapat meningkatkan prestasi belajar siswa dalam mata pelajaran IPA. Subyek penelitian tindakan bimbingan konseling ini adalah siswa kelas VIII B2 SMP Negeri 6 Singaraja Semester Ganjil Tahun Pelajaran 2018/2019. Obyek penelitian ini adalah masalah belajar IPA yang dihadapi siswa dan prestasi belajar IPA. Pemecahan masalah dalam penelitian tindakan bimbingan konseling (PTBK) ini menggunakan dua siklus yaitu siklus 1 dan siklus 2 . Teknik pengumpulan data: masalah belajar IPA dengan kuisioner, prestasi belajar IPA dengan tes belajar IPA. Hasil penelitian menunjukkan (1) melaluiteknik Konseling Eklektif dengan Perilaku Attending dapat mengatasi permasalahan belajar siswa dalam mata pelajaran IPA; (2) melaluiteknik Konseling Eklektif dengan Perilaku Attending dapat meningkatkan prestasi/hasil belajar siswa dalam mata pelajaran IPA.
\end{abstract}

Kata Kunci: Masalah Belajar IPA, Prestasi Belajar IPA, Konseling Eklektif, Perilaku Attending

\section{ABSTRACT}

The purpose of this counseling action research is (1) to describe the role of counseling with the Eclective Counseling Technique with Attending Behavior to overcome students' learning problems in science subjects, and (2) to describe the role of counseling with Eclective Counseling and Behavioral Counseling techniques. students in science subjects. The subjects of this counseling action research are class VIII B2 Singaraja State Junior High School 6 Odd Semester 2018/2019 Academic Year. The object of this research is science learning problems faced by students and science learning achievement. Problem solving in counseling action research (CAR) uses two cycles namely cycle 1 and cycle 2 . Techniques of data collection: science learning problems with questionnaires, science learning achievement with science learning tests. The results of the study show (1) through the Eclective Counseling Technique with Attending Behavior 
can overcome students' learning problems in science subjects; (2) through the Eclective Counseling technique with Attending Behavior can improve student achievement / learning outcomes in science subjects.

Keywords: Science Learning Problems, Science Learning Achievement, Eclective Counseling, Attending Behavior

\section{PENDAHULUAN}

Setiap orang sepakat bahwa pendidikan adalah investasi hidup yang paling berharga. Melalui pendidikan upaya mencetak sumber daya manusia yang berkualitas, beriman, bertaqwa kepada Tuhan Yang Maha Esa, berbudi pekerti luhur dan berkemampuan tinggi akan dapat dicapai. Sebagaimana diamanatkan dalam UUSPN No. 20/2003 bahwa pendidikan adalah usaha sadar untuk menyiapkan peserta didik melalui kegiatan bimbingan, pengajaran dan atau latihan bagi peranannya di masa yang akan datang. Bimbingan dalam konteks ini dikenal dengan istilah Bimbingan dan Konseling.Keberadaan Bimbingan dan Konseling di sekolah memberikan dampak positif terhadap perkembangan pendidikan dan pribadi siswa, hal ini mengingat banyaknya permasalahan belajar yang dialami siswa. Permasalahan belajar yang dihadapi siswa antara lain: (1) Siswa mengalami kesulitan dalam mempersiapkan kondisi fisik dan psikisnya. (2) Siswa tidak dapat mempersiapkan bahan dan peralatan sekolahnya. (3) Sarana dan prasarana di perpustakaan kurang menunjang. (4) Peralatan di laboratorium kurang lengkap, sehingga tidak dapat memberikan pelayanan yang sesuai dengan pelajaran. (5) Siswa tidak mempunyai keberanian untuk menyampaikan pertanyaan atau pernyataan dalam proses pembelajaran. (6) Siswa sering melanggar kedisiplinan kehadiran di sekolah, misalnya sering datang terlambat, sering tidak masuk sekolah, berbicara kotor, over acting ketika belajar. (7) Malas mencatat mata pelajaran. (8) Tidak menindak lanjuti proses belajar mengajar. (9) Tidak bergairah atau termotivasi dalam belajar. (10) Siswa tidak melaksanakan belajar dan diskusi kelompok. (11) Tidak bergairah dalam melaksanakan tugas atau latihan mata pelajaran. (12) Siswa malas berkonsultasi dengan guru (Ahmadi, Abu \& Supriono, Widodo, 2004). 
Dalam praktiknya penanganan masalah-masalah siswa di atas dalam kerangka bimbingan dan konseling diselesaikan melalui konseling individu maupun konseling kelompok. Berbagai teori dikemukakan oleh para ahli mengenai pendekatan atau teknik yang digunakan oleh konselor ketika proses konseling berlangsung. Pada dasarnya pendekatan/teknik konseling itu dibagi tiga (Surya: 1988) yaitu: teknik konseling direktif, non-direktif dan Eklektif. Teknik Konseling Eklektif merupakan penggabungan dua teknik Konseling Direktif dan Non Direktif. Peneliti memadukan kebaikan/kelebihan dua teknik konseling tersebut, mengembangkan dan menerapkan dalam praktek sesuai dengan permasalahan belajar siswa dengan berorientasi pada teknik hubungan antara konselor dengan klien yaitu Teknik Eklektif dengan Perilaku Attending, Dalam penelitian ini bertujuan untuk mendiskripsikan (1) peranan konseling dengan teknik Konseling Eklektif dengan Perilaku Attending dapat mengatasi permasalahan belajar siswa dalam mata pelajaran IPA, dan (2) peranan konseling dengan teknik Konseling Eklektif dengan Perilaku Attending dapat meningkatkan prestasi belajar siswa dalam mata pelajaran IPA.

\section{METODE PENELITIAN}

Jenis penelitian ini adalah jenis penelitian tindakan kelas untuk kajian bimbingan konseling.Oleh karenanya jenis penelitian ini termasuk penelitian bimbingan konseling (PTBK). Subyek PTBK ini adalah siswa kelas VIII B2 SMP Negeri 6 Singaraja Semester Ganjil Tahun Pelajaran 2018/2019 berjumlah 32 orang siswa dengan rincian 16 laki-laki dan 16 perempuan. Obyek penelitian ini adalah masalah belajar IPA yang dihadapi siswa dan prestasi belajar siswa khususnya dalam pelajaran IPA.Variabel bebasdalam penelitian ini adalah konseling eklektif dengan perilaku attending dan variabel kontrolnyaadalah masalahbelajar IPA yang dihadapi siswa dan prestasi belajar IPA.

Siklus 1.Untuk mendapatkan permasalahan dikumpulkan data mengenai masalah belajar IPA dengan menyebarkan instrument kuesioner.Data dari kuesioner lebih lanjut diolah dan diinterpretasikan untuk memperoleh gambaran masalah belajar siswa.Dengan diketahui permasalahan belajar yang dihadapi 
siswa selanjutnya dilakukan perencanaan tindakan yang mungkin dapat dilakukan secara rasional, dalam hal ini adalah penerapan bimbingan konseling ekliktif attending.Tahap berikutnya dilakukan tindakan sesuai dengan skala prioritas permasalahan yang dihadapi siswa.Hasil yang diperoleh dari tindakan ini selanjutnya digunakan sebagai bahan refleksi 1.Dari hal ini ada kemungkinkan munculnya permasalahan baru.Di samping itu, terkait dengan prestasi belajar siswa dalam mata pelajaran IPA, digunakan data awal yang dimiliki oleh guru dan data pre test dan post test yang dilaksanakan oleh guru.

Siklus 2.Pada siklus 2 dilaksanakan atas dasar bahan refleksi 1.Bila ada permasalahan baru yang muncul maka dibuatkan perencanaan tindakan dan pelaksanaan tindakan ke-2 berupa penyempurnaan bimbingan konseling eklektif attending dan model pembelajaran inovatif dalam pembelajaran IPA.Selanjutnya dilakukan observasi, refleksi dan evaluasi, untuk mencermati perubahan ke arah perbaikan atau belum.Jika tidak memerlukan perbaikan, berarti siklus sudah selesai. Namun bila belum berhasil, maka akan dilanjutkan ke siklus berikutnya. Dalam penelitian ini hanya dibatasi pada tiga siklus semata, mengingat biaya, tenaga dan waktu yang tersedia sangat terbatas.Indiktor keberhasilan dari pendekatan konseling eklektif dan atending ini adalah masalah belajar yang dihadapi siswa dapat terpecahkan dan terjadinya peningkatan hasil belajar siswa.Untuk lebih jelasnya dapat diamati pada bagan siklus penelitian berikut ini (Gambar 1).

Langkah-langkah kegiatan bimbingan konseling eklektif attending berupa: (1) Mengamati, mencatat, mengumpulkan data tentang sejauh manakah pengaruh bimbingan konseling menggunakan teknik attending eklektif terhadap motivasi/minat belajar siswa dan prestasi belajar siswa. (2) Tercapainya tujuan pokok bimbingan konseling. (3) Guru selaku konselor dalam attending selalu berupaya untuk berpenampilan baik, seperti: kepala mengangguk jika setuju dan melakukan kontak pandang dengan siswa/klien. (4) Ekspresi wajah guru/konselor tenang, ceria, tersenyum. (5) Posisi tubuh konselor agak condong kearah klien, jarak dekat, duduk akan berhadapan atau berdampingan. (6) Tangan konselor bervariasi melakukan gerakan tangan/lengan spontans berubah arah sebagai syarat 
menekankan ucapan. (7) Kesabaran mendengarkan, aktif penuh perhatian, menunggu ucapan klien hingga selesai. (8) Empati ikut merasakan apa yang dirasakan klien. (9) Merefleksi/pemantulan kembali perasaan, pikiran pengalaman klien. (10) Directing/mengarahkan klien. (11) Paraphasing/dapat menangkap pesan utama klien. (12) Interprestasi/berupaya mengulas pemikiran, perasaan, perilaku yang merujuk pada teori. (13) Bertanya membuka percakapan dan menyampaikan pertanyaan tertutup terhadap klien. (14) Minimal Encouragment atau memberikan dorongan langsung terhadap apa yang dikatakan klien. (15) Bertindak sebagai leading/memimpin arah pembicaraan. (16) Penyimpulan sementara/Summariing. (17) Memberi kesempatan kepada klien untuk feed back/mengambil kilas balik dari hal-hal yang telah dibicarakan. (18) Penyimpulan hasil secara bertahap guna meningkatkan kualitas diskusi. (19) Pemberian nasehat, informasi dan merencanakan tindakan selanjutnya.

Setting Lokasi Penelitian Tindakan Kelas Bimbingan Konseling ini di ruang kelas VIII B2 dan ruang guru BK SMP Negeri 6 Singaraja.Pembelajaran inovatif lebih menekankan pada pendekatan saintifik.Metode yang digunakan dalam pengumpulan data penelitian ini yang terkait dengan pemecahan masalah yang dihadapi dalam pembelajaran IPA adalah metode layanan atau bimbingan, wawancara, observasi, dan kuesioner.Untuk data yang terkait dengan prestasi belajar digunakan tes tulis. Instrumen yang digunakan dalam penelitian ini disesuaikan dengan kebutuhan data yang diungkap dalam penelitian, yaitu: angket, pedoman wawancara, studi dokumentasi, dan tes tulis dalam bentuk soalsoal pelajaran IPA. Data yang telah dikumpulkan, selanjutnya dianalisis sesuai dengan jenis data yang diperoleh.Data yang berkaitan dengan masalah belajar yang dihadapi siswa dan peranan bimbingan konseling eklektif attending yang diterapkan dianalisis secara deskriptif. Data tentang prestasi belajar siswa dianalisis secara deskriptif seperti ketuntasan belajar, rata-rata kelas dan peningkatan nilai yang diperoleh.

\section{HASIL DAN PEMBAHASAN}


Berdasarkan uraian di atas, sebagai sampel penelitian adalah kelas VIII B2 dengan jumlah siswa sebanyak 32 orang siswa.Dari sisi ruang untuk daya tampung sudah sesuai dengan disain pembelajaran yang ideal.Dari analisis kuesioner data 32 orang siswa tentang minat belajar IPA siswa, diperoleh hasil siswa yang senang belajar IPA sebanyak 12 orang $(37,5 \%)$ sedangkan yang tidak/kurang berminat dengan mata pembelajaran IPA adalah sebanyak 20 orang siswa $(62,5 \%)$.

Dari 10 pertanyaan yang diajukan atas dasar alasan tertentu, rerata jawaban yang diberikan $75 \%$ menyatakan ya, artinya ada relevansi alasan yang diberikan berdasarkan kuesioner.Sisanya $25 \%$ menyatakan tidak sesuai atau tidak relevan dengan alasan yang disampaikan dalam kuesioner. Alasan yang paling besar atau di atas 70\% disampaikan oleh siswa yang menyukai pelajaran IPA yang menyukai pelajaran IPA dengan alasan bahwa mereka dari tingkat sekolah dasar (SD) sudah menyukai pelajaran IPA $(83,33 \%)$, 83,33\% menyatakan senang belajar IPA dengan alasan menyukai materi/subtansi yang dipelajari dalam pelajaran IPA, 91,67\% menyatakan senang terhadap cara guru mengajar, 96,67\% juga menyatakan siswa senang karena kesabaran, perhatian, dan cara guru membimbing dalam belajar IPA, 83,33\% siswa menyatakan mudah memahami penjelasan guru, dan $75 \%$ menyatakan senang belajar IPA karena ada pekerjaan rumah sebagai tugas yang bisa dikerjakan atau dipelajari di rumah.

Disamping siswa yang senang belajar pelajaran IPA, ada sebanyak 20 orang siswa $(62,5 \%)$ yang tidak senang atau tidak berminat belajar IPA. Ada beberapa alasan yang disampaikan oleh siswa yang dijaring dalam kuesioner yakni 9 orang siswa (45\%) yang menyatakan tidak sesuai dengan cita-cita mereka di mana dari sekolah dasar mereka tidak menyukai pelajaran IPA.Ada 17 siswa (85\%) menyatakan mengalami kendala dalam mempelajari materi IPA seperti istilah-istilah dan rumus-rumus fisika yang harus dihafalkan. Ada 12 orang siswa (60\%) menyatakan belajar IPA dari buku yang dimiliki masih belum mengerti apa yang dibaca, 11 orang (55\%) menyatakan tidak akan melanjutkan ke jurusan yang berhubungan dengan pelajaran IPA. Ada sebanyak 12 orang siswa $(60 \%)$ tidak menyukai pelajaran IPA karena faktor cara guru mengajar yang kurang disukai. 
Ada sebanyak 17 orang siswa (85\%) tidak menyukai pelajaran IPA karena guru mengajar dengan cepat-cepat, kurang memperhatikan siswa yang belum mengerti, sering memberikan pekerjaan rumah, dan marah-marah bila tidak memperhatikan pelajaran. Ada 16 orang siswa (80\%) menyatakan sangat sulit memahami penjelasan guru, karena penuh dengan istilah-istlah latin atau rumus-rumus yang saya tidak mengerti. Secara umum dapat dinyatakan bahwa ada 11 orang siswa $(56,1 \%)$ yang menyatakan bahwa mereka tidak menyukai atau tidak berminat terhadap pelajaran IPA baik karena faktor cita-cita, materi dari pelajaran IPA, dan cara guru mengajar. Alasan lainnya yang disampaikan oleh siswa, ada sebanyak 9 orang siswa $(43,9 \%)$ yang menyatakan bukan karena faktor waktu dan biaya yang dimiliki siswa bila ada biaya tambahan seperti praktikum di laboratorium, atau di lapangan dan juga bukan faktor buku, dan juga bukan faktor pekerjaan rumah (PR) yang diberikan guru. Jadi secara ringkas dapat dinyatakan bahwa sebagian besar siswa mengalami beberapa masalah yang dihadapi sehingga mereka tidak senang belajar IPA, di antaranya masalah internal seperti cita-cita dan karir dan faktor eksternal seperti faktor guru, buku, dan kondisi sosial siswa.

Terkait dengan konseling yang dirancang untuk diberikan kepada siswa, ada 26 orang siswa (81\%), yang menyatakan pentingnya peran guru BK sebagai tempat untuk konseling, konsultasi, memecahkan masalah yang dihadapi, konseling untuk dapat meningkatkan hasil belajar IPA, dan konseling untuk dapat meningkatkan minat terhadap pelajaran IPA. Hanya sebagaian kecil, yakni 6 orang siswa (18\%) yang menggap tidak penting atas peran guru BK dalam membantu meningkatkan minat dan hasil belajar IPA.

Perlu juga disampaikan terhadap kondisi sampel dalam hal nilai yang telah dikumpulkan oleh guru pengajar IPA sebelum pelaksanaan PTBK ini.Adapun kondisi nilai awal mata pelajaran IPA sebelum dilaksanakannya PTBK ini disajikan pada Tabel 1.Dari Tabel 1 tampak bahwa bagi kelompok yang menyukai atau berminat terhadap pelajaran IPA menunjukkan nilai awal yang bagus, dengan nilai yang diperoleh sebagian siswa sudah di atas KKM dan sebagian lagi mendekatai KKM.KKM yang dipasang oleh guru pengajar IPA adalah 76.Di satu sisi, tampak bahwa bagi siswa yang tidak menyukai/tidak berminat pelajaran IPA 
menunjukkan nilai yang sangat rendah, dan jauh dari KKM yang dipasang oleh guru.

Untuk memperjelas hasil pelaksanaan PTBK ini dari siklus I dan siklus II perlu dilakukan komparasi baik untuk hasil konseling maupun kemajuan hasil belajar.

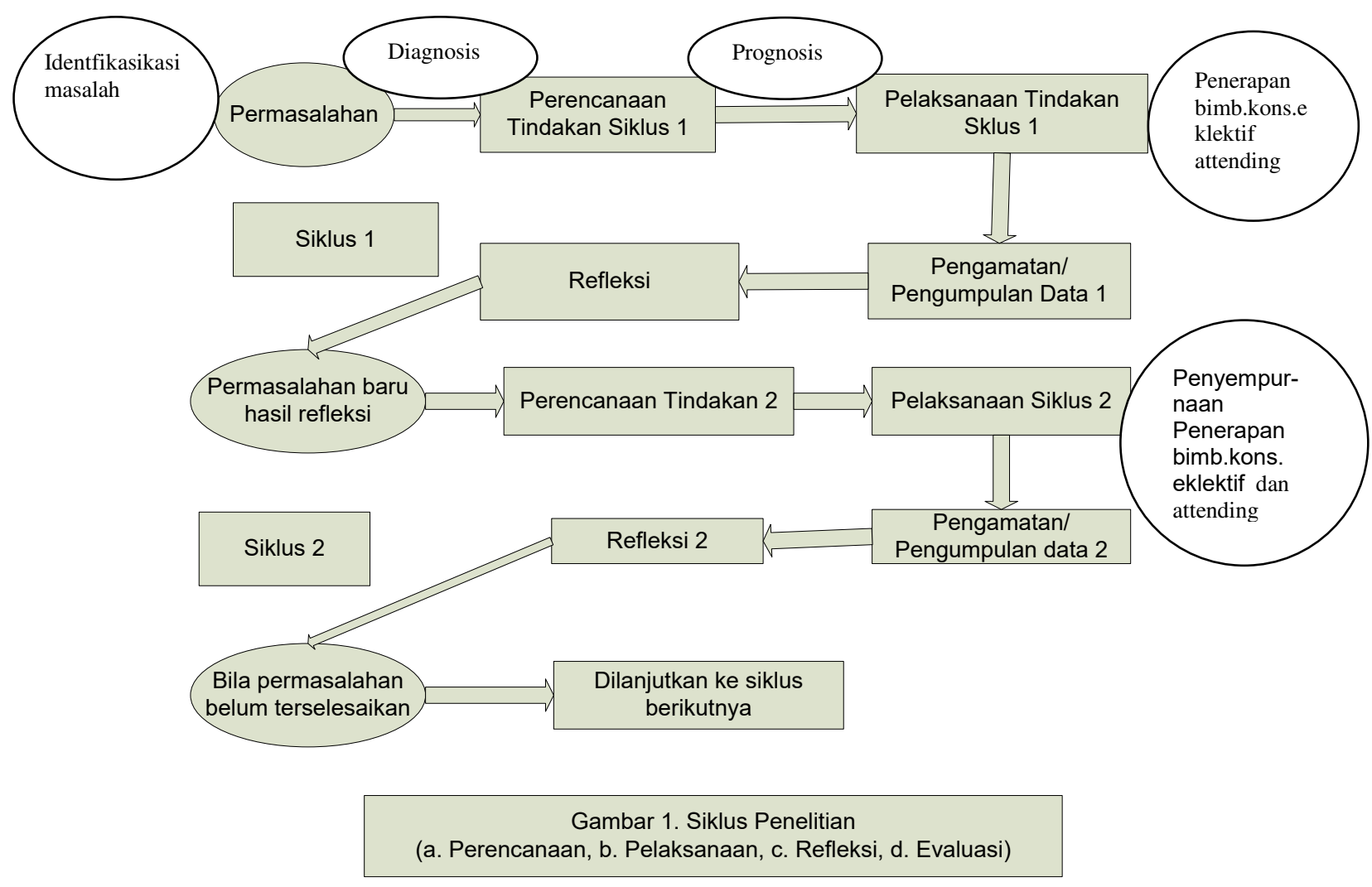

Tabel 1. Nilai Awal Untuk Siswa yang Menyukai/Berminat Pelajaran IPA

\begin{tabular}{|c|c|c|c|c|c|}
\hline \multirow[t]{2}{*}{ NO } & \multicolumn{2}{|c|}{$\begin{array}{c}\text { SISWA YANG MENYUKAI } \\
\text { PELAJARAN IPA }\end{array}$} & \multirow[t]{2}{*}{ NO } & \multicolumn{2}{|c|}{$\begin{array}{c}\text { SISWA YANG TIDAK MENYUKAI } \\
\text { PELAJARAN IPA }\end{array}$} \\
\hline & NAMA SISWA & NILAI & & NAMA SISWA & NILAI \\
\hline 1 & Kadek Vina Septiani & 80 & 1 & Ida Ayu Deviya Adhista & 53 \\
\hline 2 & Deadi Pranajaya & 95 & 2 & Komang Awanda Wulandari & 50 \\
\hline 3 & Putu Agus Pratama Suputra & 75 & 3 & Kadek Wangi Dwi Wahyuni & 36 \\
\hline 4 & Gede Natawan & 90 & 4 & Alya Nanda Dewi & 46 \\
\hline 5 & Komang Sugiarta & 80 & 5 & Putu Visna Mahayani & 60 \\
\hline 6 & Kadek Agus Suardika & 80 & 6 & $\begin{array}{l}\text { Made Diah Intan Nopilya } \\
\text { Murtisari }\end{array}$ & 33 \\
\hline 7 & Komang Ardi Widyawan & 85 & 7 & Kadek Dwi Rahayu Wirandani & 43 \\
\hline
\end{tabular}




\begin{tabular}{|llccll|}
8 & Ni Putu Mira Sepiani & 70 & 8 & Kadek Indri Sukmayanti & 46 \\
& Kartikasari & & & & \\
9 & Putu Saras & 75 & 9 & I Putu Berlan Marjuanda Putra & 30 \\
10 & Komang Puspa Candra Dewi & 70 & 10 & I Kadek Janu Mahendra Putra & 36 \\
11 & Luh Putu Febriasih & 70 & 11 & Ketut Juni Sumerta Wijaya & 63 \\
12 & Kadek Cindy Pratiwi & 75 & 12 & Putu Angga Raditya Wiguna & 43 \\
13 & & & 13 & Ngurah Arya Adi Putra & 36 \\
14 & & 14 & Kadek Riski Dwi Artana Putra & 44 \\
15 & & 15 & Putu Iwan Karyana & 36 \\
16 & & 16 & Ida Bagus Dwi Ari Purnawan & 23 \\
17 & & 17 & Kadek Angga Dwipayana & 46 \\
18 & & 18 & Komang Laksmi Dewi & 53 \\
19 & & 19 & Kadek Gayatri & 42 \\
20 & & 20 & Made Anggun Parwati & 40 \\
\hline
\end{tabular}

Hasil janji solusi yang disepakati baik pada siklus I dan II dapat dilihat pada Tabel 2.

Tabel 2. Perbandingan hasil Janji Solusi pada Siklus I dan Sklus II

\begin{tabular}{|c|c|c|c|c|c|c|c|c|c|}
\hline \multirow[t]{4}{*}{ NO } & \multirow{4}{*}{$\begin{array}{l}\text { KATEGORI JANJI SOLUSI } \\
\text { YANG DISAMPAIKAN SISWA }\end{array}$} & \multicolumn{8}{|c|}{ HASIL PENGAMATAN } \\
\hline & & \multicolumn{4}{|c|}{ SUDAH DILAKUKAN } & \multicolumn{4}{|c|}{$\begin{array}{c}\text { BELUM } \\
\text { DILAKUKAN }\end{array}$} \\
\hline & & \multicolumn{2}{|c|}{ Siklus I } & \multicolumn{2}{|c|}{ Siklus II } & \multicolumn{2}{|c|}{ Siklus I } & \multicolumn{2}{|c|}{ Siklus II } \\
\hline & & $\sum_{\text {Siswa }}^{\sum}$ & $\%$ & $\sum_{\text {Siswa }}$ & $\%$ & $\sum_{\text {Siswa }}^{\sum}$ & $\%$ & $\sum_{\text {Siswa }}$ & $\%$ \\
\hline 1 & $\begin{array}{l}\text { Membawa buku pelajaran IPA ke } \\
\text { sekolah }\end{array}$ & 17 & 85 & 20 & 100 & 3 & 15 & 0 & 0 \\
\hline 2 & $\begin{array}{l}\text { Membuat catatan penting/resume } \\
\text { pada buku catatannya sebagai tanda } \\
\text { siswa telah membaca di rumah }\end{array}$ & 12 & 60 & 20 & 100 & 8 & 40 & 0 & 0 \\
\hline 3 & $\begin{array}{l}\text { Memperhatikan guru pada saat } \\
\text { menjelaskan di depan kelas }\end{array}$ & 8 & 40 & 20 & 100 & 12 & 60 & 0 & 0 \\
\hline 4 & $\begin{array}{l}\text { Membuat catatan tambahan dalam } \\
\text { buku catatan untuk melengkapi } \\
\text { catatan yang telah dibuat di rumah }\end{array}$ & 8 & 40 & 20 & 100 & 12 & 60 & 0 & 0 \\
\hline 5 & $\begin{array}{l}\text { Mengajukan pertanyaan kepada } \\
\text { guru bila belum mengerti atau tidak } \\
\text { jelas }\end{array}$ & 5 & 25 & 18 & & 15 & 75 & 2 & \\
\hline 6 & $\begin{array}{l}\text { Bertanya kepada temannya setelah } \\
\text { pelajaran di kelas selesai }\end{array}$ & 17 & 85 & 20 & 100 & 3 & 15 & 0 & 0 \\
\hline 7 & Belajar kelompok di rumah & 4 & 20 & 16 & & 16 & 80 & 4 & \\
\hline 8 & $\begin{array}{l}\text { Membeli buku tambahan selain } \\
\text { buku "paket/wajib" }\end{array}$ & 3 & 15 & 20 & 100 & 17 & 85 & 0 & 0 \\
\hline 9 & $\begin{array}{l}\text { Membaca buku di perpustakaan } \\
\text { yang terkait dengan pelajaran IPA }\end{array}$ & 9 & 45 & 18 & & 11 & 55 & 2 & \\
\hline
\end{tabular}




\section{yang telah dijelaskan di kelas}

10 Berdiskusi tentang pelajaran IPA sekolah pada saat jam pelajaran lain kosong

Dari Tabel 2 tampak bahwa ada kemajuan terhadap pemenuhan janji solusi yang telah disepakati oleh siswa yang kurang berminat terhadap pelajaran IPA, dimana pada siklus I janji solusi yang terpenuhi hanya mencapai $45 \%$, sedangkan pada siklus II mencapai 96\%.Yang belum terpenuhi berupa pembelian buku-buku selain buku wajib yang dimiliki oleh siswa (yang diberikan di sekolah).Hal ini sangat dipahami bahwa kondisi orang tua siswa yang masuk ke SMP Negeri 6 ini adalah termasuk ke dalam kategori ekonomi menengah ke bawah.

Hasil belajar pada siklus I dan II disajikan pada Tabel 3.

Tabel 3. Perbandingan Hasil Belajar pada Siklus I dan II

\begin{tabular}{|c|c|c|c|c|c|c|}
\hline No & Nama Siswa & $\begin{array}{l}\text { Nilai } \\
\text { Awal }\end{array}$ & $\begin{array}{c}\text { Siklus } \\
\text { I }\end{array}$ & $\begin{array}{c}\text { Rerata } \\
\text { Kemajuan } \\
\text { Nilai } \\
\text { Awal- } \\
\text { Siklus I } \\
\end{array}$ & $\begin{array}{c}\text { Siklus } \\
\text { II }\end{array}$ & $\begin{array}{c}\text { Rerata } \\
\text { Kemajuan } \\
\text { Siklus I-II }\end{array}$ \\
\hline 1 & Ida Ayu Deviya Adhista & 53 & 76,5 & 23,5 & 80 & 3,5 \\
\hline 2 & Komang Awanda Wulandari & 50 & 79 & 29 & 86 & 7,0 \\
\hline 3 & Kadek Wangi Dwi Wahyuni & 36 & 77 & 41 & 83,5 & 6,5 \\
\hline 4 & Alya Nanda Dewi & 46 & 68,5 & 22,5 & 77,5 & 9,0 \\
\hline 5 & Putu Visna Mahayani & 60 & 87,5 & 27,5 & 92,5 & 5,0 \\
\hline 6 & $\begin{array}{l}\text { Made Diah Intan Nopilya } \\
\text { Murtisari }\end{array}$ & 33 & 76 & 43 & 80 & 4,0 \\
\hline 7 & $\begin{array}{l}\text { Kadek Dwi Rahayu } \\
\text { Wirandani }\end{array}$ & 43 & 77,5 & 34,5 & 90 & 12,5 \\
\hline 8 & Kadek Indri Sukmayanti & 46 & 86,5 & 40,5 & 90 & 3,5 \\
\hline 9 & $\begin{array}{l}\text { I Putu Berlan Marjuanda } \\
\text { Putra }\end{array}$ & 30 & 32,5 & 2,5 & 77,5 & 4,5 \\
\hline 10 & $\begin{array}{l}\text { I Kadek Janu Mahendra } \\
\text { Putra }\end{array}$ & 36 & 49 & 13 & 85 & 3,6 \\
\hline 11 & Ketut Juni Sumerta Wijaya & 63 & 83,5 & 20,5 & 95 & 11,5 \\
\hline 12 & $\begin{array}{l}\text { Putu Angga Raditya } \\
\text { Wiguna }\end{array}$ & 43 & 43,5 & 0,5 & 77,5 & 3,4 \\
\hline 13 & Ngurah Arya Adi Putra & 36 & 39 & 3 & 77,5 & 38,5 \\
\hline 14 & $\begin{array}{l}\text { Kadek Riski Dwi Artana } \\
\text { Putra }\end{array}$ & 44 & 77 & 33 & 80 & 3,0 \\
\hline 15 & Putu Iwan Karyana & 36 & 49 & 13 & 87,5 & 38,5 \\
\hline 16 & Ida Bagus Dwi Ari & 23 & 78,5 & 55,5 & 85 & 6,5 \\
\hline
\end{tabular}


Jurnal IKA Vol. 17, No.1 Maret 2019

ISSN 1829-5282

Purnawan

17 Kadek Angga Dwipayana $\quad \begin{array}{llllll}76 & 74 & 28 & 80 & 6,0\end{array}$

18 Komang Laksmi Dewi $\quad 53 \quad 77,5 \quad 24,5 \quad 87,5 \quad 10,0$

19 Kadek Gayatri $\quad 42 \quad 56 \quad 14 \quad 82,5 \quad 26,5$

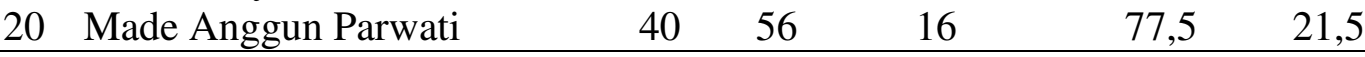

$\begin{array}{llllll}\text { Rerata } & 42,95 & 67,2 & 24,25 & 83,30 & 16,1\end{array}$

Berdasarkan Tabel 3 tampak bahwa rerata kemajuan hasil belajar siswa terhadap pelajaran IPA adalah sebesar 16,1. Hal ini berarti siswa yang awalnya kurang berminat belajar IPA, menjadi lebih berminat untuk belajar IPA.Pada siklus I masih ada siswa yang belum tuntas sedang pada siklus II semua siswa telah tuntas. Dilihat dari ketutasannya rata-rata nilai ulangan dari siklus I dan siklus II adalah 67,20 dan 83,30. Hal ini berarti pada siklus I secara umum belum tercapai ketuntasan belajarnya.Akan tetapi secara individu telah mencapai ketuntasannya sampai mencapai 8 orang siswa (40\%), sedangkan yang belum tuntas ada sebanyak 12 orang siswa (60\%).Ketuntasan belajar yang dipasang oleh guru IPA adalah nilai 76.Pada siklus II baik ketutasan secara umum maupun ketuntasan secara keseluruhan telah tercapai $100 \%$.

Berdasarkan hasil penelitian yang telah diuraikan di atas, ada kemajuan dalam meningkatkan minat siswa untuk belajar IPA dengan menerapkan teknik hubungan antara konselor dengan klien yaitu teknik eklektif dengan perilaku attending. Hasil konseling menujukkan bahwa dalam bimbingan konseling eklektif attending siswa dibuat senyaman mungkin dalam mengikuti konseling yang diberikan oleh guru BK. Dengan demikian siswa menjadi lebih nyaman, terbuka, dan tidak ada batas antara guru BK dengan siswa (dalam arti bahwa konseling lebih bersifat familier). Pada siklus I ini siswa telah bersepakat untuk mengikuti solusi yang dibuat oleh siswa itu sendiri bersama guru BK (Peneliti), seperti terlihat pada tabel di atas. Pada siklus II, siswa sudah menjadi lebih nyaman, dan sangat senang bertemu dengan guru BK, dan pada saat konseling kelompok, mereka mengajukan pertanyaan, pendapat dan saran-saran yang bersifat terbuka, jujur, dan penuh dengan rasa kekeluargaan. Di samping itu indikator yang dipakai juga adalah hasil belajar siswa dan ketuntasan hasil belajar. Dari hasil belajar siswa diperoleh rata-rata nilai ulangan dari siklus I dan siklus II 
adalah 67,20 dan 83,30. Hal ini berarti pada siklus I secara umum belum tercapai ketuntasan belajarnya.Akan tetapi secara individu telah mencapai ketuntasannya sampai mencapai 8 orang siswa (40\%), sedangkan yang belum tuntas ada sebanyak 12 orang siswa (60\%).Ketuntasan belajar yang dipasang oleh guru IPA adalah nilai 76.Pada siklus II baik ketuntasan secara umum maupun ketuntasan secara keseluruhan telah tercapai $100 \%$.

Dari hasil penelitian ini menunjukkan bahwa peran konseling kepada siswa sangat besar perannya dalam hal untuk membantu siswa dalam memecahkan masalah yang dihadapi. Hal ini sesuai dengan batasan dari bimbingan konseling itu sendiri yakni Bimbingan dan Konseling adalah pelayanan bantuan untuk peserta didik, baik secara perorangan maupun kelompok, agar mampu mandiri dan berkembang secara optimal, dalam bidang pengembangan kehidupan pribadi, kehidupan sosial, kemampuan belajar, dan perencanaan karir, melalui berbagai jenis layanan dan kegiatan pendukung, berdasarkan norma-norma yang berlaku. Demikian juga dilihat dari fungsi konseling yang relevan dengan hasil penelitian ini yakni (1) Pemahaman, yaitu fungsi untuk membantu peserta didik memahami diri dan lingkungannya. (2) Pencegahan, yaitu fungsi untuk membantu peserta didik mampu mencegah atau menghindarkan diri dari berbagai permasalahan yang dapat menghambat perkembangan dirinya. (3) Pengentasan, yaitu fungsi untuk membantu peserta didik mengatasi masalah yang dialaminya. (4) Pemeliharaan dan pengembangan, yaitu fungsi untuk membantu peserta didik memelihara dan menumbuhkembangkan berbagai potensi dan kondisi positif yang dimilikinya. Dan (5) Advokasi, yaitu fungsi untuk membantu peserta didik memperoleh pembelaan atas hak dan atau kepentingannya yang kurang mendapat perhatian.

Dalam penerapan konseling kepada siswa yang mengalami masalah terhadap pembelajaran IPA yaitu kurang menyukai pelajaran IPA digunakan teknik konseling eklektif dimana teknik koseling ini sebagai penggabungan antara teknik direktif dan nondirektif.Hal ini sesuai dengan pengertian dari Teknik Konseling Eklektif yaitu merupakan penggabungan dua pendekatan Direktif dan Non-Direktif.Konseling Eklektif yang mengambil berbagai kebaikan/kelebihan 
dari dua kebaikan/kelebihan dari dua pendekatan atau dari berbagai teori konseling, mengembangkan dan menerapkan dalam praktek sesuai dengan permasalahan klien. Konseling Eklektif lebih tepat dan sesuai dengan filsafat tujuan bimbingan dan konseling dari pada sikap yang hanya mengandalkan satu pendekatan satu pendekatan atau satu dua teori tertentu saja (Surya, 1988).

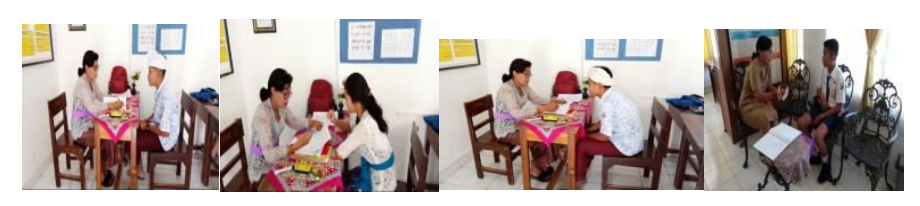

Gambar 2. Konseling Individu dengan Teknik Ekliktif Attending pada Siklus I

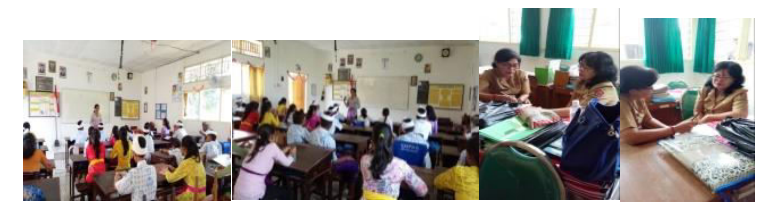

Gambar 3.Konseling Kelompok dengan Teknik Ekelktif Attending yang Dilakukan di Kelas dan Diskusi antara Guru BK dan Guru IPA pada Siklus II.

Perilaku Attending (teknik menghadapi klien) melalui kontak mata, badan, bahasa lisan, sehingga klien akan terlihat dalam pembicaraan terbuka. Attending baik untuk meningkatkan harga diri klien yang bebas. Perlu dihindari konselor berpenampilan attending yang kurang baik seperti: kepala kaku, muka kaku, ekspresi melamun, mengalihkan pandangan, tidak terlihat saat klien sedang bicara, mata melotot. Posisi tubuh bersandar miring, tegak kaku, jarang duduk, jarak duduk menjauh, duduk kurang akrab, dan berpaling.Memutuskan pembicaraan, berbicara terus tanpa ada teknik diam untuk memberi kesempatan klien guna berpikir dan berbicara.Perhatian konselor terpecah, mudah buyar oleh gangguan (Willis, 2004).Perilaku attending disebut juga perilaku menghampiri klien yang mencakup komponen kontak mata, bahasa tubuh, dan bahasa lisan. Perilaku attending yang baik dapat: (1) Meningkatkan harga diri klien. (2) Menciptakan suasana yang aman. (3) Mempermudah ekspresi perasaan klien dengan bebas. Contoh perilaku attending yang baik: Kepala: melakukan anggukan jika setuju, Ekspresi wajah: tenang, ceria, senyum, Posisi tubuh: agak condong ke arah klien, jarak antara konselor dengan klien agak dekat, duduk akrab 
berhadapan atau berdampingan. Tangan: variasi gerakan tangan/lengan spontan berubah-ubah, menggunakan tangan sebagai isyarat, menggunakan tangan untuk menekankan ucapan. Mendengarkan: aktif penuh perhatian, menunggu ucapan klien hingga selesai, diam (menanti saat kesempatan bereaksi), perhatian terarah pada lawan bicara. Contoh perilaku attending yang tidak baik: Kepala: kaku, Muka: kaku, ekspresi melamun, mengalihkan pandangan, tidak melihat saat klien sedang bicara, mata melotot. Posisi tubuh: tegak kaku, bersandar, miring, jarak duduk dengan klien menjauh, duduk kurang akrab dan berpaling. Memutuskan pembicaraan, berbicara terus tanpa ada teknik diam untuk memberi kesempatan klien berfikir dan berbicara. Perhatian: terpecah, mudah buyar oleh gangguan luar.

Dalam kaitannya dengan pembelajaran IPA, hasil penelitian Wijana (2008) menyatakan bahwa dengan pembelajaran yang menekankan pada suasana kelas yang kondusif, nyaman, aman, dan memperhatikan kesehatan lingkungan dapat meningkatkan motivasi belajar dan menurunkan rasa kebosanan. Pernyataan ini juga diperkuat oleh pendapat yang disampaikan oleh Sugiyanto (2000); Sadiman, dkk (2005); Sudjana dan Rivai (2002) yang menyatakan bahwa media pembelajaran itu adalah memiliki fungsi yang jelas yaitu memperjelas, memudahkan siswa memahami konsep/teori, dan membuat pesan kurikulum yang akan disampaikan kepada siswa agar lebih menarik, sehingga motivasi belajar siswa meningkat dan proses belajar dapat lebih efektif dan efesien.

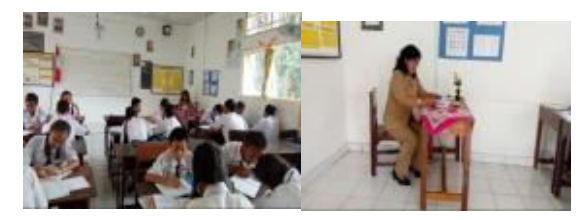

Gambar 4.Cara Guru IPA Mengajar pada Siklus I Dimana Guru Mengajar dengan Cara Duduk dan Bersifat Monoton

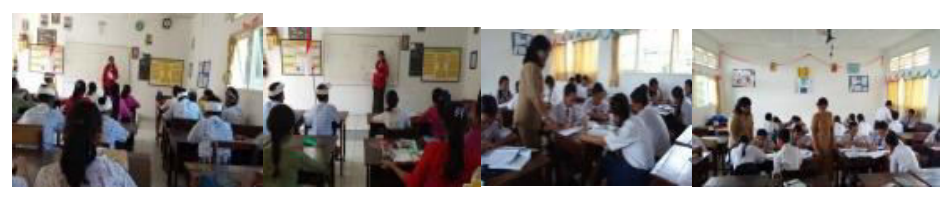

Gambar 5. Guru IPA Sedang Mengajar di Kelas pada Siklus II di mana Pola Pembelajarannya Sudah Menunjukkan Adanya Variasi Mengajar Sesuai dengan Hasil Diskusi dengan Peneliti. Peneliti 
Ikut Serta Di Dalam Kelas untuk Mengamati Kegiatan Siswa

Dalam Proses Belajar Mengajar.

\section{SIMPULAN DAN SARAN}

Dari hasil penelitian ini dapat disimpulkan bahwa (1) teknik Konseling Eklektif dengan Perilaku Attending dapat mengatasi permasalahan belajar siswa dalam mata pelajaran IPA; (2) teknik Konseling Eklektif dengan Perilaku Attending dapat meningkatkan prestasi/hasil belajar siswa dalam mata pelajaran IPA.

Dari simpulan di atas, ada beberapa saran yang dapat direkomendasikan yaitu: (1) Konseling yang dilakukan kepada siswa dengan menggunakan teknik eklektif attending sangat efektif untuk membantu memecahkan masalah yang dihadapi siswa, terutama pada pelajaran IPA, oleh karenanya disarankan kepada guru-guru BK untuk dapat menerapkan teknik eklektif attending sebagai salah satu teknik untuk melakukan konseling; (2) Guru mata pelajaran IPA di dalam melaksanakan proses belajar mengajar di kelas, sebaiknya memperhatikan kondisi siswa terutama dalam hal penerapan metode pembelajaran, menjaga atmosfir kelas, bersifat kekeluargaan, nyaman, dan kondusivitas kelas tetap terjaga.

\section{DAFTAR PUSTAKA}

Calhoun, J.F. dan Acocella, J.R. Alih bahasa oleh RS.Satmoko.(1995). Psikologi tentang Penyesuaian dan Hubungan Kemanusiaan. Semarang: IKIP Semarang Press.

Dahar, Ratna W. (1996). Teori-teori Belajar. Jakarta: Erlangga.

Rahayu. E. H. Susanto, D. Yulianti. 2011. Pembelajaran Sains Dengan Pendekatan Keterampilan Proses Untuk Meningkatkan Hasil Belajar Dan Kemampuan Berpikir Kreatif Siswa. Jurnal Pendidikan Fisika Indonesia 7 (2011): 33-37.

Sadiman, Arief S. dkk. 2005 Media Pendidikan: Pengertian, Pengembangan, dan Pemanfaatannya. Jakarta: PT. Raja Grafindo Persada. 
Sudjana, Nana dan Ahmad Rivai. 2002. Media Pengajaran. Bandung: Sinar Baru Algesindo.

Sugiyanto, 2008.Model-model Pembelajaran Kooperatif.Surakarta : Depdikbud

Sukartini, Sri Patmah. (2003). Model Konseling Keterampilan Hidup untuk Mengembangkan Dimensi Kendali Pribadi yang Tegar. Disertasi Doktor pada PPS UPI Bandung: tidak diterbitkan.

Surya, Moh (1988), Dasar- Dasar Konseling Pendidikan (Konsep dan Teori), Yogyakarta: Kota Kembang

Wijana, Nyoman. 2008. Pembelajaran Sains Melalui Pendekatan Ergonomi Mengurangi Keluhan Muskuloskeletal, Kebosanan Dan Kelelahan Serta Meningkatkan Motivasi dan Prestasi Belajar Siswa SD 1 Sangsit Kecamatan Sawan Kabupaten Buleleng

Willis, Sofyan S. (2005). Remaja dan Masalahnya. Bandung: Alfabeta 